Urban Studies, Vol. 32, Nos. 4-5, 1995 733-757

\title{
Immigration and Internal Migration 'Flight' from US Metropolitan Areas: Toward a New Demographic Balkanisation
}

\author{
William H. Frey
}

\section{Introduction}

An earlier review of the new urban revival in the US (Frey, 1993a) pointed up that a key ingredient of this revival involves sharp spatial disparities in the growth patterns between the nation's white population and its racial and ethnic minorities. These patterns diverged enough to warrant speculation that new race and ethnic-based demographic divisions may be emerging which may impact upon the economies, politics and attitudes toward multiculturalism in different parts of the country (Frey, 1995a).

Clearly, the larger, ethnically diverse waves of immigration to the US during the 1980s and 1990s (Center for Immigration Studies, 1994; Fix and Passe1, 1994; Martin and Midgley, 1994; Chiswick and Sullivan, 1995) have affected redistribution dynamics within the country that hold important consequences for broad regions, states and entire metropolitan areas. The approximately 10 million legal and illegal immigrants that entered the US between 1980 and 1990 exceeded the number for any other decade of this century. Over 85 per cent of them came from Asian and Latin American countries. If the current immigration law remains in place, a similar volume and national origin makeup will characterise the 1990s cohort of immigrants, as well. Yet, the popular perception that the US is becoming a more diverse population with respect to race, ethnicity and other demographic attributes associated with these new immigrants at the national level (Roberts, 1993), does not characterise many local regions or metropolitan areas. Rather, the new immigration and internal migration patterns appear to be exacerbating these differences by contributing to a 'demographic balkanisation' across broad regions and areas of the country.

Existing evidence for this argument is based, largely, on an analysis of recent immigration and internal migration for US states which shows that:

(1) most immigrants are directed to a small number of destinations;

(2) most recent internal migrants are directed to different destinations from those attracting immigrants; and

(3) the appearance of a 'push-pull' relationship between immigrant flows and internal out-migration for states receiving the greatest numbers of immigrants.

These dynamics suggest an emerging division across broad areas according to their dominant immigration or internal migration contributions. The most dramatic demographic changes will likely occur in the high immigration areas where immigration from abroad represents a much more dominant source of gain than internal migration. Moreover, the additional 'flight' of internal

William H. Frey is at the Population Studies Center, The University of Michigan, 1225 South University Avenue, Ann Arbor, MI 48104-2590, USA. A supplementary report with detailed 1990 census migration statistics for US metropolitan areas is Research Report 94-304 available from Publications, Population Studies Center, The University of Michigan. This research is supported by NICHD grant ROI-29725 and NIA grant ROI-AG12291. 
migrants from these areas, in response to either economic or social considerations, will contribute even further to their demographic distinctiveness.

The purpose of this article is to examine these migration dynamics for metropolitan areas rather than states. The metropolitan area is a more meaningful unit for evaluating this phenomenon because it represents a labour market area that both immigrants and long-distance internal migrants will consider as a destination (Frey and Speare, 1988; Long, 1988). Using newly available 1990 census migration census tabulations, ${ }^{1}$ this paper evaluates how the nation's metropolitan areas are being impacted by the emerging immigration and internal migration dynamics. It addresses the questions:

(1) Is there a distinction emerging between metropolitan areas where population change is dominated by immigration from abroad, and areas where change is dominated by internal migration?

(2) Are there unique patterns of internal out-migration from immigrant-dominant metropolitan areas, for Non-Latino whites ${ }^{2}$ and other internal migrants?

(3) Does immigration exert an independent effect on the magnitude and socio-economic selectivity on internal migration of Non-Latino whites from US metropoli$\tan$ areas?

The findings presented below provide affirmative responses to each of these questions. They suggest that the immigration and internal migration processes are leading to a greater demographic balkanisation - a spatial segmentation of the population by race-ethnicity and socio-economic status across metropolitan areas. Before proceeding with the metropolitan area analysis, a brief overview at the state level is presented.

\section{A Migration Classification of States}

The evaluation of detailed census migration data for the 1985-90 period makes plain that states can be classified on the basis of their dominant immigration and internal migration dynamics (see Frey, 1994a, for a fuller discussion). This typology is presented in Figure 1. It classifies the 17 states that are most dominated by migration into three categories:

High immigration states (California, New York, Texas, New Jersey, Illinois, Massachusetts). These states have the largest 1985-90 migration from abroad where the immigration component overwhelms net internal migration.

High internal migration states (Florida, Georgia, North Carolina, Virginia, Washington, Arizona). These states showed greatest net increases in their internal exchanges with other states over the 1985-90 period. Also, in each case (including Florida), gains from internal migration significantly exceeded those from immigration.

High out-migration states (Louisiana, Michigan, Ohio, Oklahoma, Iowa). These states showed greatest net out-migration in their exchanges with other states and did not receive large immigration gains over the 198590 period.

It is not surprising that most immigrants gravitate to only a few 'port-of-entry' states. Latin Americans and Asians, among these waves, typically locate in places with existing racial and ethnic enclaves (Bean and Tienda, 1987; Bartel, 1989; Barringer et al., 1993; Fix and Passel, 1994). What is significant about these 'high immigration states' is that they are not attracting similarly large numbers of internal migrants. In fact, five of the six show a net internal out-migration over the 1985-90 period (Table 1), and in the remaining state (California), its relatively small net in-migration turned to out-migration since 1990 (Bolton, 1993). The out-migration phenomenon means that internal migrants are far less constrained by social networks and other ties than are immigrants in selecting destinations. Moreover, during the period studied, other parts of the country were economically and socially more attractive to internal migrants than were the high immigration states. 


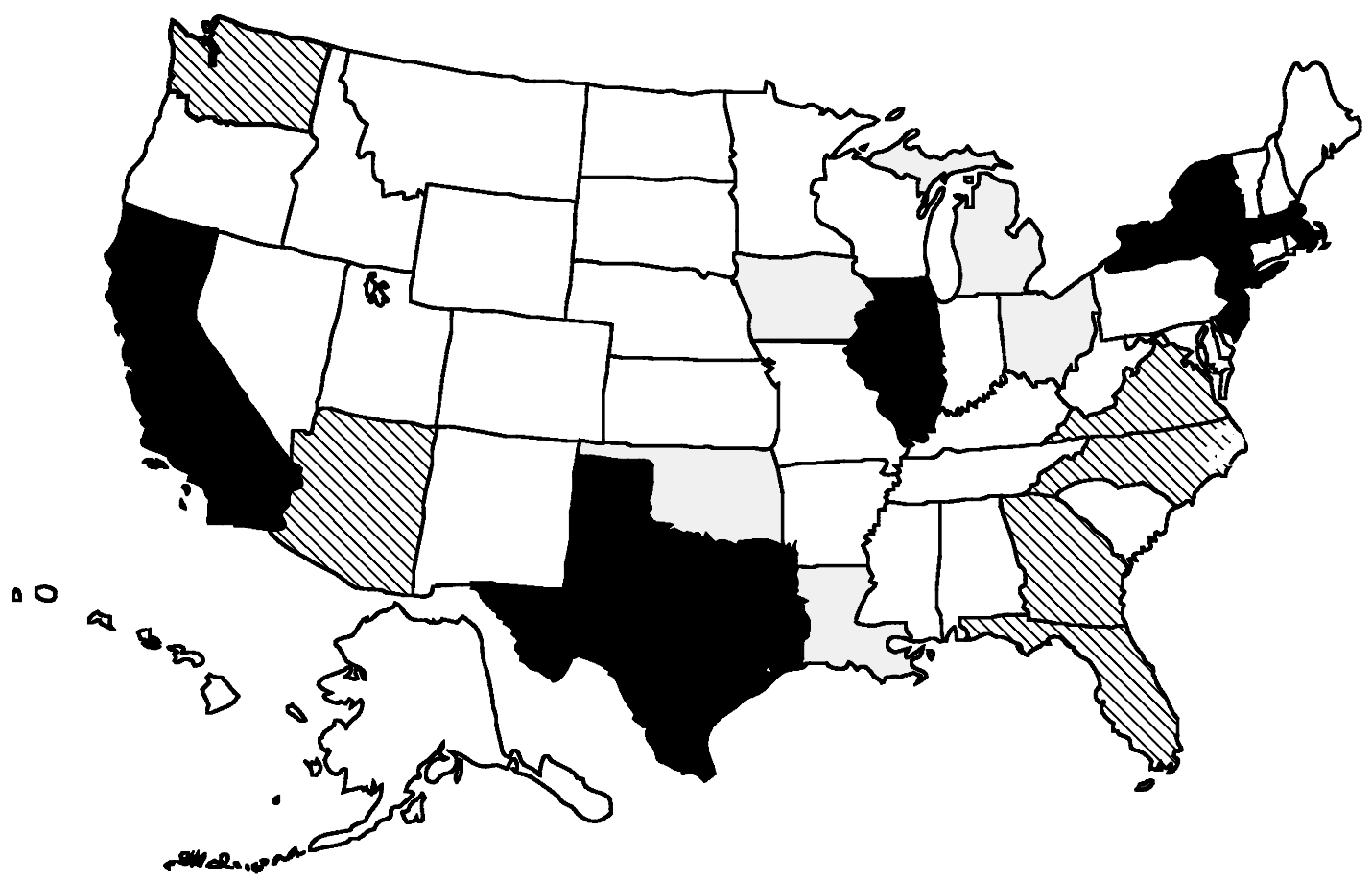

High immigration states

$\$$ High internal migration states

High out-migration states

Figure 1. Migration classification of states.

One implication of these flows for high immigration states is an increase in their minority populations resulting from immigration dominated by new minoritiesLatinos and Asians and, in some cases, an out-migration that is largely white (see California and New York in Figure 2). This contrasts sharply with the whitedominant internal migration gains (in some cases supplemented by substantial black in-migration) which accrue to 'high internal migration states' (see Florida and Georgia in Figure 2).

In addition to these racial selectivity distinctions in migration, previous research has pointed up that the out-migrants from high immigration states are also unique in their social and economic selectivity. Typically, long-distance migration might be characterised as a 'circulation of 'elites' which proportionately selects on higher-income, better educated and professional migrants. Under this process, losing states tend to show disproportionate losses among these valued demographic groups, while gaining states tend to increase their ranks in these categories (see Lansing and Mueller, 1967; Frey, 1979; and Long, 1988). This 'circulation of élites' model does not appear to apply to outmigration from the high immigration states, however. The out-migration from these states tends to select on the lower socio-economic ranks. Their out-migration rates tend to be highest for whites with below-poverty incomes, and with low college graduate education attainment levels. These patterns are 
Table 1. Classification of states by dominant immigration and interstate migration contributions to population change, 1985-90

\begin{tabular}{|c|c|c|c|}
\hline \multirow[b]{2}{*}{ Rank } & \multirow[b]{2}{*}{ State } & \multicolumn{2}{|c|}{ Contribution to $1985-90$ change (1000s) } \\
\hline & & Migration from abroad ${ }^{\mathrm{a}}$ & $\begin{array}{l}\text { Net interstate } \\
\text { Migration }^{\mathrm{b}}\end{array}$ \\
\hline \multicolumn{4}{|c|}{ 1. High immigration states ${ }^{\mathrm{c}}$} \\
\hline 1 & California & 1499 & 174 \\
\hline 2 & New York & 614 & -821 \\
\hline 3 & Texas & 368 & -331 \\
\hline 4 & New Jersey & 211 & -194 \\
\hline 5 & Illinois & 203 & -342 \\
\hline 6 & Massachu setts & 156 & -97 \\
\hline \multicolumn{4}{|c|}{ 2. High internal migration states ${ }^{\mathrm{d}}$} \\
\hline 1 & Florida & 390 & 1071 \\
\hline 2 & Georgia & 92 & 303 \\
\hline 3 & North Carolina & 66 & 281 \\
\hline 4 & Virginia & 149 & 228 \\
\hline 5 & Washington & 102 & 216 \\
\hline 6 & Arizona & 80 & 216 \\
\hline \multicolumn{4}{|c|}{ 3. High out-migration states $\mathrm{e}$} \\
\hline 1 & Louisiana & 30 & -251 \\
\hline 2 & Ohio & 69 & -141 \\
\hline 3 & Michigan & 74 & -133 \\
\hline 4 & Oklahom a & 32 & -128 \\
\hline 5 & Iowa & 17 & -94 \\
\hline
\end{tabular}

Source: Compiled from 1990 Census files at the Population Studies Center, The University of Michigan.

${ }^{\mathrm{a}} 1990$ state residents who resided abroad in 1985 .

${ }^{\mathrm{b}} 1985-90$ in-migrants from other states minus 1985-90 out-migrants to other states. ${ }^{\mathrm{c}}$ States with largest 1985-90 migration from abroad which exceeds net interstate migration.

${ }^{\mathrm{d}}$ States with largest 1985-90 net interstate migration and exceeds migration from abroad.

${ }^{\mathrm{e}}$ States with largest negative net interstate migration and not recipients of large migration from abroad.

not consistent with the conventional wisdom on internal migration, nor are they consistent with the movement away from high out-migration states, which do not have significant immigration (such as Louisiana, Iowa or Ohio).

This 'downwardly-selective' out-migration of whites from high immigration states may reflect the impact of immigrant competition for low-skilled service or manufacturing jobs, for affordable housing, and perhaps some aversion to the new racial and ethnic diversity on the part of many whites (see interviews with Tilove and Hallinan, 1993; and the results from earlier studies of 1980 census statistics in Manson et al., 1985; Filer, 1992; Walker et al., 1992; White and Hunter, 1993; and White and Imai, 1994). Among other implications of this immigration-internal migration linkage is an impending sharp increase in the minority compositions, and of the less-educated, lower-income populations of these states. It is the nature of this selective 'flight' that questions 2 and 3 (above) will address for metropolitan areas. 


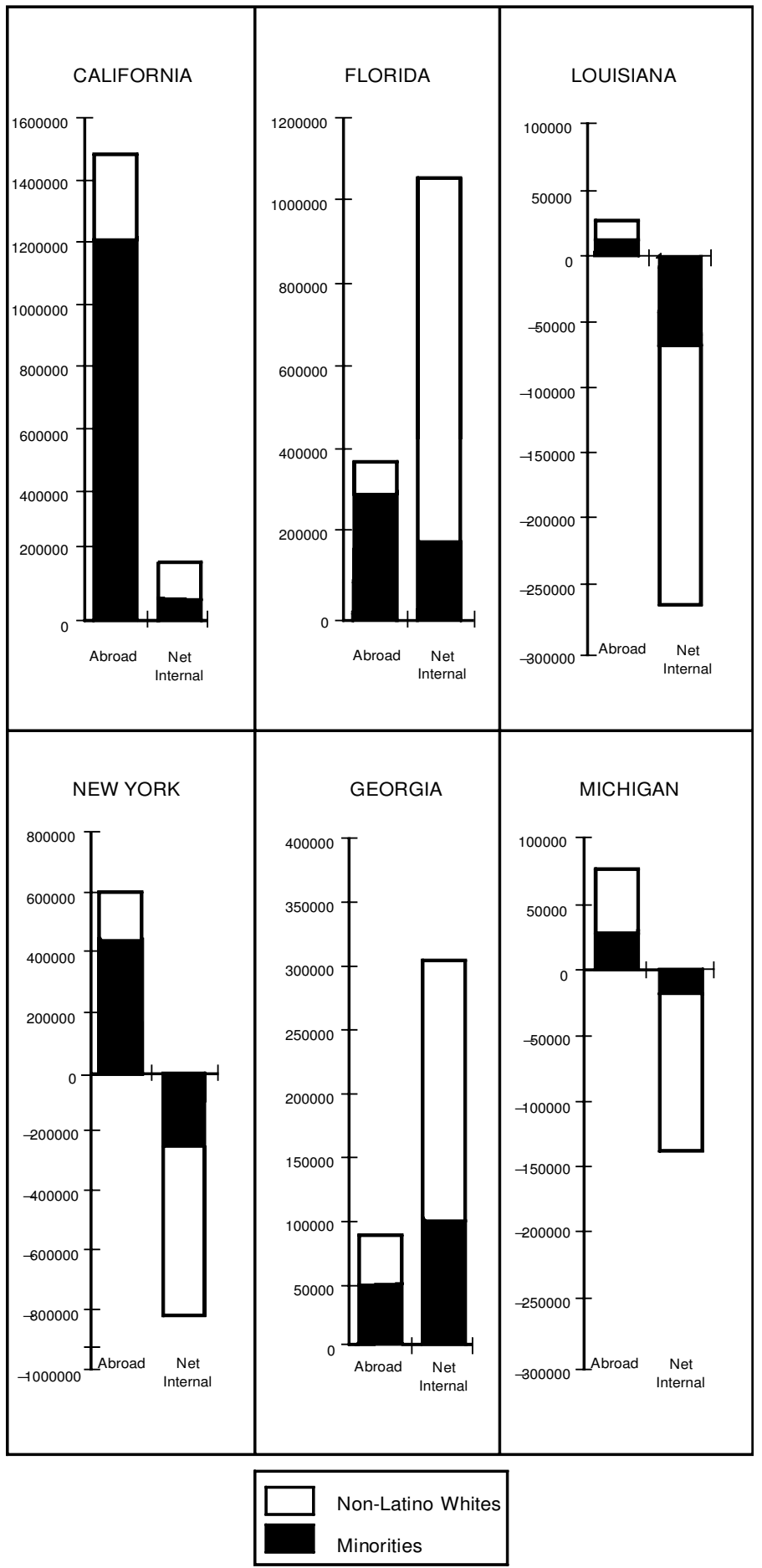

Figure 2. Migration from abroad and net internal migration by race, selected states, 1985-90: unshade $d=$ Non-Latino whites; black $=$ minorities . 
A Migration Classification of Metropolitan Areas

A classification of large metropolitan areas according to dominant immigration or internal migration contributions is presented in Table 2. This classification pertains to metropolitan areas with 1990 populations of greater than 1 million, as well as selected additional metropolitan areas (metros) where 1985-90 net internal migration exceeded $50000 .{ }^{3}$ As with the earlier classification of states, 'high immigration metros' pertain to metropolitan areas with the greatest numerical 1985-90 immigration from abroad; 'high internal migration metros' are metropolitan areas which display greatest 1985-90 gains from internal migration; and 'high outmigration metros' are areas which show high levels of out-migration without being compensated by large immigration flows. The residual set of metropolitan areas includes those where immigration and internal migration are not sufficiently large to warrant placing in any of the three categories.

This classification demonstrates that major metro areas which are significantly affected by migration are dominated by either immigration from abroad or by net internal migration. For the most part, high immigration metros show either negative or relatively small gains from net internal migration. Similarly, population gains in high internal metros come primarily from the migration exchanges with other parts of the country. The singular exception, among these two categories, is San Diego which gains substantially from both immigration and internal migration sources. While San Diego has been arbitrarily placed in the high immigration metro class, this distinction should be recognised.

Not surprisingly, there are strong regional commonalities between the metros in each of the three migration classes and the corresponding states shown in Table 1. That is, most high immigration metros are located in the high immigration states of California, Texas, Illinois, New York and selected other eastern seaboard states. High internal migration metros are located, largely, in the South Atlantic region of the US, and in selected western states.

The advantage of using metro areas rather than states for this classification scheme is pointed up in the case of Florida. In the earlier scheme, Florida was characterised as a high internal migration state. However, the new metro scheme makes a sharper distinction of metro areas within the state. Miami is clearly dominated by migration from abroad, whereas the five Florida areas classed as high internal migration metros are strongly dominated by gains from other parts of the US. In like manner, Sacramento is classed as a high internal migration metro, distinct from the other California immigration magnet areas.

Just as the high internal migration metros are located in parts of the country that prospered economically during this recent migration period, the high out-migration metros are located in interior portions of the country which did not do as well. These include metros in the Midwest 'rust belt' states which were still reeling in the aftermath of the early 1980s deindustrialisation phenomenon. Also on the list is New Orleans, located in the economically depressed 'oil patch' region, and Denver, whose economy slumped somewhat during the late 1980s.

What this scheme makes plain is that immigration from abroad will affect some major metro areas much more heavily than the rest of the country. This is significant because irrespective of the economic cycles and amenity preferences which serve to drive flows of internal migration, immigration from abroad tends to focus on the same 'port-of-entry' high immigration metro destinations as in the past. To the extent that these areas continue to attract large immigration flows, their population compositions will become more distinct-reflecting the demographic characteristics of immigrants much more so than other metro areas. (See the race-ethnic compositions of the immigrant flows to Los Angeles, San Francisco, Chicago and New York in Figure 3.) Already, the 1990 census statistics show that these areas are much more diverse in 
Table 2. Classification of large metro areas by dominant immigration and internal migration contributions to population change, 1985-90

\begin{tabular}{|c|c|c|c|}
\hline \multirow[b]{2}{*}{ Metro areas ${ }^{\mathrm{a}}$} & \multicolumn{2}{|c|}{ Contribution to $1985-90$ change } & \multirow{2}{*}{$\begin{array}{c}\text { Percentage } \\
\text { minority } \\
1990\end{array}$} \\
\hline & $\begin{array}{l}\text { Immigration } \\
\text { from abroad }\end{array}$ & $\begin{array}{l}\text { Net internal } \\
\text { migration }\end{array}$ & \\
\hline \multicolumn{4}{|c|}{ 1. High immigration metros } \\
\hline Los Angeles & 899007 & -174673 & 50 \\
\hline New York & 756034 & -1065580 & 37 \\
\hline San Francisco & 293306 & -103498 & 39 \\
\hline Miami & 210609 & 45287 & 52 \\
\hline Washington DC & 190941 & 33634 & 37 \\
\hline Chicago & 179524 & -293185 & 33 \\
\hline Boston & 119646 & -116506 & 13 \\
\hline San Diego & 115847 & 126855 & 35 \\
\hline Houston & 96782 & -142227 & 42 \\
\hline Philadelphia & 79975 & -28400 & 24 \\
\hline Dallas & 77301 & 27435 & 30 \\
\hline \multicolumn{4}{|c|}{ 2. High internal migration metros } \\
\hline Atlanta & 42878 & 192065 & 30 \\
\hline Tampa-St Petersberg & 34623 & 159112 & 17 \\
\hline Seattle & 63870 & 146026 & 15 \\
\hline Phoenix & 43861 & 139678 & 23 \\
\hline Orlando & 35153 & 132449 & 23 \\
\hline Las Vegas & 20551 & 128680 & 25 \\
\hline Sacramento & 36380 & 117732 & 27 \\
\hline West Palm Beach & 21485 & 107940 & 21 \\
\hline Charlotte & 8926 & 66961 & 22 \\
\hline Raleigh-Durhram & 12451 & 66088 & 28 \\
\hline Portland & 24335 & 60733 & 10 \\
\hline Norfolk & 33236 & 56292 & 33 \\
\hline Nashville & 7569 & 57639 & 17 \\
\hline Fort Myers & 3469 & 57613 & 12 \\
\hline Daytona Beach & 5137 & 55074 & 14 \\
\hline \multicolumn{4}{|c|}{ 3. High out-migration metros } \\
\hline Detroit & 45417 & -136352 & 25 \\
\hline Pittsburgh & 10720 & -89759 & 9 \\
\hline New Orleans & 10270 & -88356 & 41 \\
\hline Cleveland & 20597 & -79925 & 19 \\
\hline Denver & 28127 & -61360 & 20 \\
\hline St Louis & 19132 & -37262 & 20 \\
\hline Milwaukee & 13062 & -34801 & 19 \\
\hline Buffalo & 10717 & -30572 & 14 \\
\hline \multicolumn{4}{|l|}{ Other large metros } \\
\hline Columbus, Oh & 13933 & 44622 & 14 \\
\hline Minneapolis-St Paul & 28112 & 40277 & 9 \\
\hline Baltimore & 33706 & 29566 & 29 \\
\hline Indianapolis & 8141 & 15278 & 16 \\
\hline Kansas City & 13962 & 13269 & 17 \\
\hline Providence & 26910 & 11860 & 9 \\
\hline Cincinnati & 9517 & 9259 & 13 \\
\hline Hartford & 24628 & -5143 & 17 \\
\hline San Antonio & 29372 & -11600 & 56 \\
\hline Rochester & 10884 & -14691 & 14 \\
\hline Salt Lake City & 14940 & -20525 & 10 \\
\hline
\end{tabular}

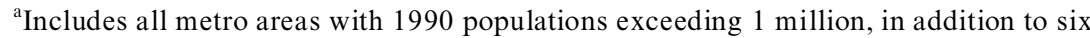
smaller areas which registered 1985-90 net internal migration exceeding 50000 . The metropolitan area definitions are consistent with Office of Management and Budget definitions of CMSAs, MSAs and NECMA counterparts as of 30 June 1990.

Source: Special Tabulation of full Migration Sample of the 1990 US Census compiled at the Population Studies Center, University of Michigan. 
terms of their minority population compositions (see last column of Table 2). Of the 11 high immigration metros, only 2 show minority percentages below the nation's combined minority percentage ( 25 per cent). This is not the case for most of the other large metropolitan areas in the country, including most high internal migration metros. (See how recent internal migration reinforces these patterns for Tampa-St Petersburg, Phoenix and Las Vegas in Figure 3.) Many of these show minority percentages well below the national figure. Some of the exceptions to this (e.g. Atlanta, Raleigh-Durham, Detroit, Las Vegas) include substantial native-born black populations among the internal in-migrants.

\section{Migrant Selectivity by Social and Econ- omic Characteristics}

The different race-migration dynamics that appear to be associated with metro areas of different classes, can also be linked to selectivity patterns on measures of poverty status, education attainment and the migration of the elderly. These patterns follow from the earlier suggestion that high immigration to a metropolitan area may trigger different selectivity patterns of internal out-migration that does not conform to the more typical 'circulation of 'elites' model of long-distance migration in the US. Prior to discussing characteristic internal migration patterns associated with the different metro categories in the typology, a more general national overview of metropolitan area net migration is presented.

\section{National Patterns}

While the migration statistics in Table 2 point up areas that show the greatest total internal migration gains and losses, these patterns are not replicated by each race and ethnic group, or social and economic category of migrant. To gain some perspective on this, rankings of the greatest gaining and greatest losing metropolitan areas, for different demographic categories, are presented in
Tables 3, 4 and 5. These rankings pertain to net internal migration for the demographic sub-groups shown.

Metropolitan area gainers and losers, via net migration for whites and blacks, are shown in Table 3 and Figure 4. These data make plain that the overall net gains shown for South Atlantic, and some Pacific and mountain states, mask somewhat different preferences for whites and blacks. NonLatino whites are most heavily drawn to Florida and western states, whereas black gains are more strongly directed to Atlanta and other South Atlantic metro areas outside Florida. While the general movement of blacks back to the historic southern region continues a pattern set in the previous decade (Long, 1988; McHugh, 1987, 1988; Frey and Speare, 1988; Johnson and Roseman, 1990), this movement has become more focused toward South Atlantic destinations in the recent period (Frey, 1994b). Net migration loss patterns are also somewhat distinct between these two broad race groups. While New York shows the greatest net out-migration for all racial and demographic categories considered, blacks show a greater outpouring from areas with large black communities that have recently suffered hard times. For example, Detroit, New Orleans and Cleveland rank higher on the list of black net out-migration than is the case for Non-Latino whites. The five greatest internal out-migration metros for whites are also on the list of high immigration metros. The link between immigration and white net out-migration will be explored further below.

As in the past, both Asian and Latino internal migration destinations are understandably different from those of whites and the largely native-born black population (McHugh, 1989; Massey et al., 1987; Bean and Tienda, 1987; Bartel, 1989; Bartel and Koch, 1991; and Barringer et al., 1993) (see Table 4). Yet it is important to note that there is some internal migration away from traditional immigration 'ports-of-entry' among Asians (e.g. from New York, Honolulu and Chicago) and Latinos (e.g. New York, Los Angeles, San Francisco, Chicago and several 


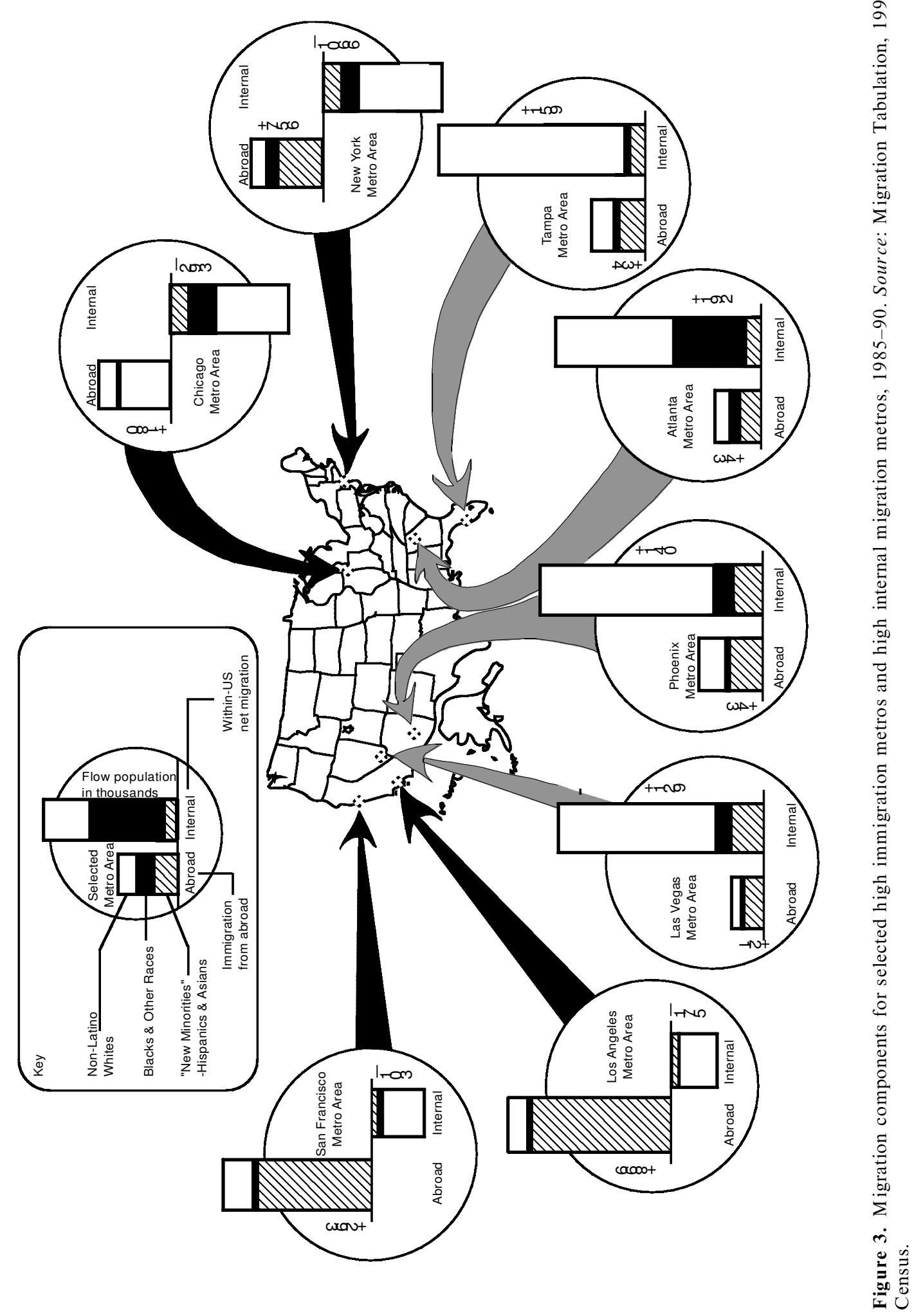


Table 3. List of metro areas with greatest net internal migration gains and losses 1985-90, Non-Latino whites and blacks

\begin{tabular}{clrll}
\hline \multicolumn{5}{c}{ Greatest gains/losses due to net internal migration } \\
\cline { 3 - 5 } Rank & \multicolumn{3}{c}{ Non-Latino Whites ${ }^{\mathrm{a}}$} & \multicolumn{2}{c}{ Blacks } \\
\hline Gains & & & \\
1 & Tampa-St Petersburg & 141056 & Atlanta & 74949 \\
2 & Seattle & 129204 & Norfolk & 28909 \\
3 & Phoenix & 116367 & Washington, DC & 20205 \\
4 & Atlanta & 102297 & Raleigh-Durham & 17428 \\
5 & Las Vegas & 99633 & Dallas & 16075 \\
6 & West Palm Beach & 99301 & Orlando & 13836 \\
7 & Orlando & 99743 & Richmond & 12508 \\
8 & San Diego & 87522 & San Diego & 12482 \\
9 & Sacramento & 83718 & Minneapolis-St Paul & 11506 \\
10 & Charlotte & 57012 & Sacram ento & 10848 \\
Losses & & & & \\
1 & New York & -705498 & New York & -191700 \\
2 & Chicago & -191483 & Chicago & -69593 \\
3 & Los Angeles & -136158 & Detroit & -19114 \\
4 & Boston & -124816 & New Orleans & -16271 \\
5 & Houston & -120151 & Los Angeles & -11731 \\
6 & Detroit & -114684 & Cleveland & -11576 \\
7 & Pittsburgh & -83432 & St Louis & -10444 \\
8 & San Francisco & -79797 & San Francisco & -7078 \\
9 & Cleveland & -67278 & Shreveport & -5075 \\
10 & New Orleans & -60727 & Pittsburgh & -4899 \\
\hline
\end{tabular}

${ }^{a}$ Non-Latino whites are estimated as: Whites + other races - Latinos.

Source: Special Tabulation of full Migration Sample of the 1990 US Census compiled at the Population Studies Center, University of Michigan.

border metros in Texas). While these internal migration patterns suggest the potential for a greater dispersion of more assimilated Asians and Latinos, the magnitudes of these flows represent but a trickle in comparison with the large immigrant waves which are being directed to high immigration metros.

Metropolitan area gainers and losers for categories of poverty status, college graduates and the elderly population are shown in Table 5. In general, they make plain that college graduates are directed to a very different set of metros from either the broad non-poverty population or the poverty population. College graduates tend to locate in large economically dynamic metro areas, including several that are high immigration metros, such as Los Angeles, San Francisco, Washington, DC, and Dallas. It is not a coincidence that these same immigration magnets are also losing poverty migrants (see Figure 5). This is consistent with the literature which shows that new immigrants may be pushing out lower-skilled native-born internal migrants, as a result of job and housing competition-at the same time that the presence of a large immigrant population helps to foster a 'dual economy' which will attract college graduates and professionals (Waldinger, 1989; Mollenkopf and Castells, 1991; White and Hunter, 1993).

Finally, consistent with earlier studies (Longino, 1984, 1990; Rogers and Watkins, 1987; Rogers, 1992; Frey, 1995c), these data point up the very strong elderly movement to retirement centres in various parts of the Sunbelt. Tampa-St Petersburg, West Palm Beach, Phoenix and Las Vegas are the greatest gaining metros for both the total elderly and the Non-Latino white elderly. The greatest origins of elderly net out-migration include the large Frost Belt metros of New 
Table 4. List of metro areas with greatest net internal migration gains and greatest migration from abroad, 1985-90, A sians and Latinos

\begin{tabular}{|c|c|c|c|c|}
\hline \multirow[b]{2}{*}{ Rank } & \multicolumn{4}{|c|}{ Greatest gains } \\
\hline & Asians & & Latinos & \\
\hline \multicolumn{5}{|c|}{ Gains from internal migration } \\
\hline 1 & Los Angeles & 31804 & Miami & 48270 \\
\hline 2 & Sacram ento & 11203 & Orlando & 23701 \\
\hline 3 & San Francisco & 10345 & San Diego & 19711 \\
\hline 4 & San Diego & 6355 & Las Vegas & 16216 \\
\hline 5 & Boston & 5364 & Tampa-St Petersburg & 13763 \\
\hline 6 & Atlanta & 4760 & Dallas & 12271 \\
\hline 7 & Seattle & 3990 & Phoenix & 11127 \\
\hline 8 & Washington, DC & 3854 & Sacramento & 11053 \\
\hline 9 & Orlando & 3842 & Modesto & 10072 \\
\hline 10 & Las Vegas & 3326 & Washington, DC & 9912 \\
\hline \multicolumn{5}{|c|}{ Gains from abroad } \\
\hline 1 & Los Angeles & 219652 & Los Angeles & 520653 \\
\hline 2 & New York & 190512 & New York & 269141 \\
\hline 3 & San Francisco & 137006 & Miami & 144692 \\
\hline 4 & Chicago & 44823 & San Francisco & 86222 \\
\hline 5 & Washington, DC & 43481 & Chicago & 72719 \\
\hline 6 & San Diego & 31274 & San Diego & 54704 \\
\hline 7 & Boston & 27219 & Washington, DC & 51721 \\
\hline 8 & Seattle & 26817 & Houston & 50433 \\
\hline 9 & Philade lphia & 22347 & Boston & 34831 \\
\hline 10 & Houston & 21258 & Dallas & 34662 \\
\hline
\end{tabular}

${ }^{\mathrm{a}}$ Non-Latino whites are estimated as: Whites + other races - Latinos.

Source: Special Tabulation of full Migration Sample of the 1990 US Census compiled at the Population Studies Center, University of Michigan.

York, Chicago, Detroit, Boston, Philadelphia, Cleveland and Pittsburgh. However, large numbers of elderly are also leaving Los Angeles, San Francisco and Washington, DC-metros in somewhat warmer climates but with high costs and drawing immigrant populations.

\section{High Immigration Metros}

The analysis now turns to the issue of whether or not there exists a unique pattern of selective out-migration from high immigration metros. This can be assessed from an examination of these metro areas' net migration percentages specific to poverty status, education attainment and elderly status. These statistics are shown in Table 6 for the 11 high immigration metros.

The unique selectivity pattern of net out- migration, anticipated for these areas, is one which accentuates the exodus of the leastskilled and lower-income non-minority residents of these areas. These groups, it was argued, are most impacted by the increased competition from immigrants for jobs and housing. 'Flight' from foreign immigrants or unfamiliar minorities may also be a consideration to the extent they translate into social costs resulting from increased services, provision for multi-lingual schools and related issues. Similarly, the 'elites' who are known to circulate as a result of more conventional migration patterns may be much less affected by the impact on minorities. For these reasons, college graduates and higher-income individuals may be less likely to move out and more likely to move in, to the extent that prosperous high-income and professional jobs may be available in such areas. 


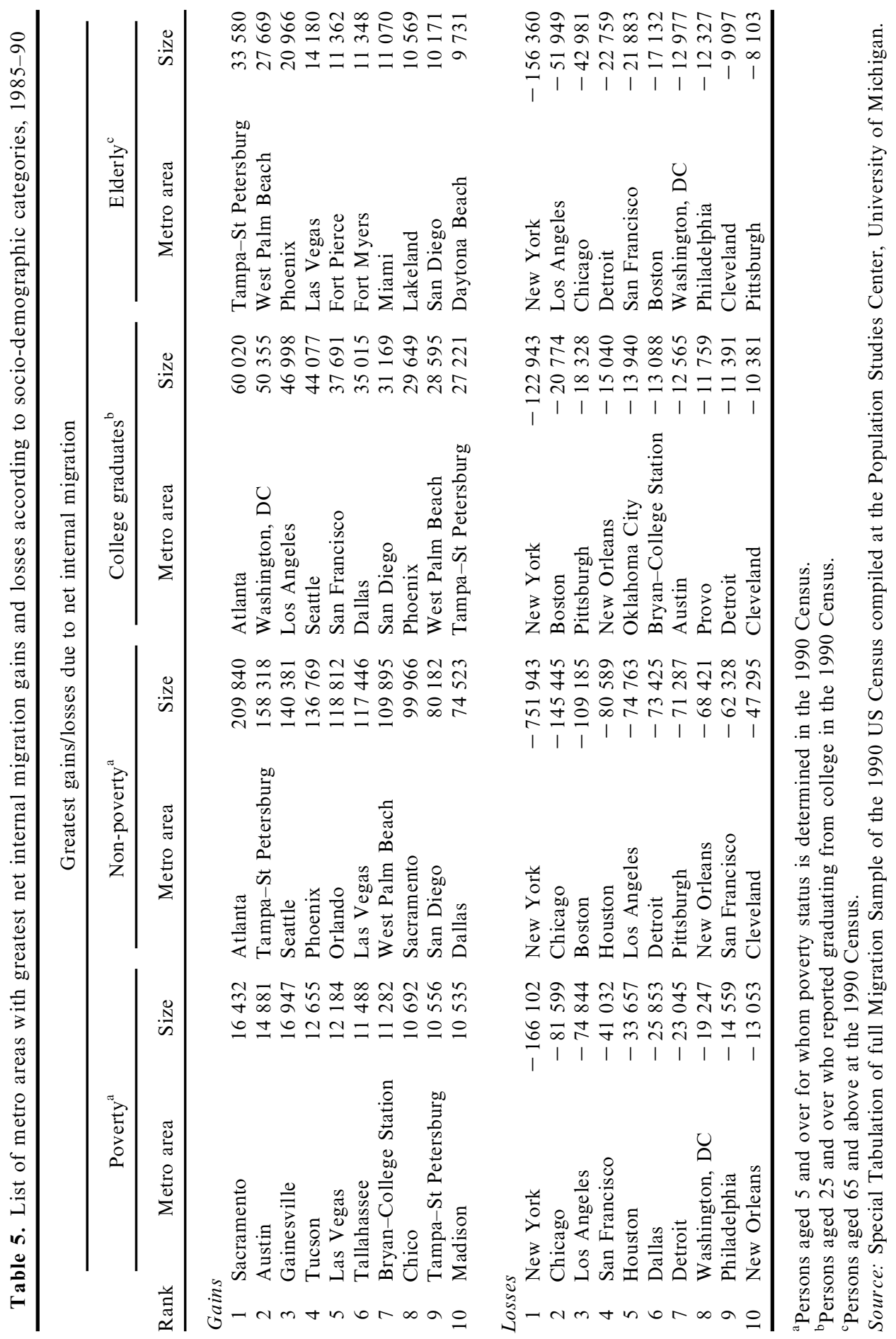


WHITES

.0 $\infty$

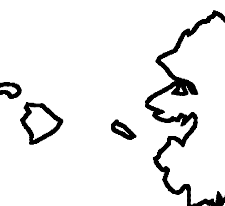
Anex

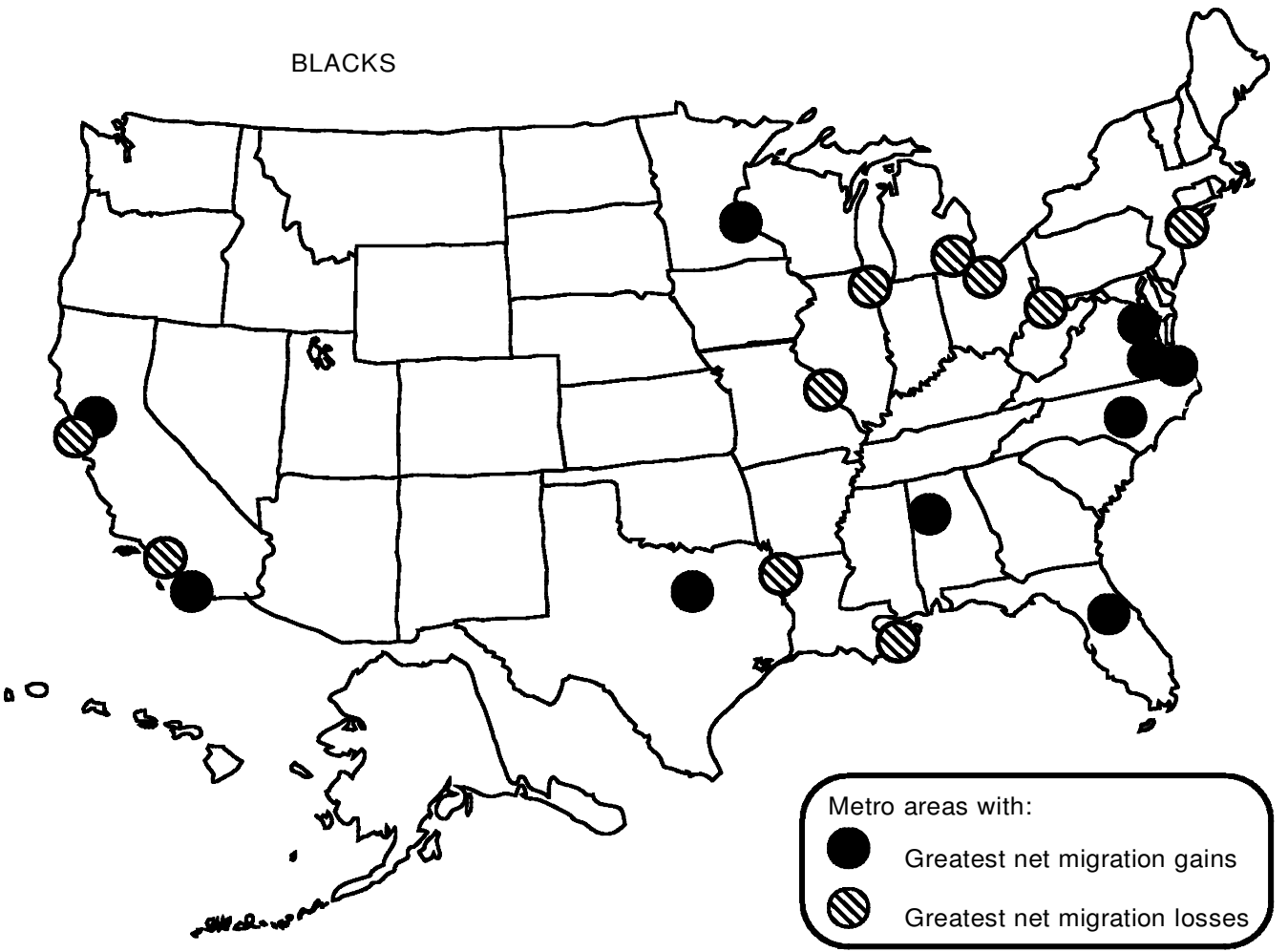

Figure 4. Metro area net internal migration, 1985-90: Non-Latino whites (above) and blacks (below). 
The data in Table 6 pretty much bear out these assertions. That is, for most high immigration areas, poverty internal out-migration is much higher than that for non-poverty populations, and the net out-movement is somewhat higher for Non-Latino whites than for the total population. With respect to education attainment, several areas (including Los Angeles, San Francisco, Washington, DC, Philadelphia and Dallas) show a pattern of net in-migration of college graduates and a net out-migration of both high school graduates and high school dropouts. Again, these patterns tend to be more accentuated for the Non-Latino white population than for the total population.

Clearly, there are variations across metropolitan areas in these patterns. They are most muted in areas with a positive net migration from other parts of the country (e.g. San Diego, Miami) and in areas where the volume of immigration is large but where the rate of immigration is not (e.g. Philadelphia, Chicago). New York, also, does not conform entirely to this high immigration metro pattern in the sense that it displays significant net out-migration for high as well as low education attainment categories. Also, the out-migration percentage for its non-poverty population is higher than for any of the other metros in this class.

These data also seem to suggest that the elderly population may be more apt to relocate away from high immigration metros. It is not surprising to find significant elderly net out-migration from northern metropolitan areas such as New York, Chicago, Boston and Philadelphia. It is noteworthy that the elderly in Los Angeles, San Francisco and Washington, DC, show substantially higher out-migration percentages than their total populations. Only Miami and San Diego, two well-known retirement destinations, show positive net in-migration of the total and Non-Latino white elderly populations.

Further evidence, consistent with the view that immigrants are displacing internal migrants at the lower rungs of the socioeconomic spectrum, is shown with the immigration percentages in the top panels of
Table 6. In most cases, the se selective immigration patterns are a mirror image of internal net out-migration-that is, immigrants tend to be disproportionately concentrated in the poverty population and those with less than high school educations. There is a bimodal distribution of immigrants on educational attainment such that immigrant percentages are higher for college graduates, as well as for those with less than high school educations. Nonetheless, the latter percentage tends to be higher and has a much larger aggregate impact on the local economy and demographic structure.

\section{High Internal Migration and High Out- migration Metros}

If the internal migration selectivity associated with high immigration metros is unique because it selects on the lower rung of the socio-economic scale, then the migration processes affecting these two metro classes should be more typical-reflecting the 'circulation of élites' model. Migration percentages shown in Table 7 on the whole confirm that this model is an appropriate characterisation of selective net in-migration to high internal migration metros-that is, in most cases, all categories of poverty status and education attainment show net in-migration, and the percentages are greatest for college graduates and the non-poverty populations.

In Orlando, for example, college graduates move in at almost twice the percentage of college dropouts, and among Non-Latino whites, this ratio is 3 to 1 . One exception to this is Raleigh-Durham, where poverty $\mathrm{mi}$ grants move in at a higher rate than those above poverty, and the distinction is not sharp with respect to education attainment. This may be attributable to the return migration of white and black residents from the north, which may take in some elderly migrants as well. Two other areas that deviate from the 'circulation of 'elites' model are also worthy of note. These are Las Vegas and Sacramento which show uniformly high rates of internal in-migration across poverty and education categories. Evidence shown else- 


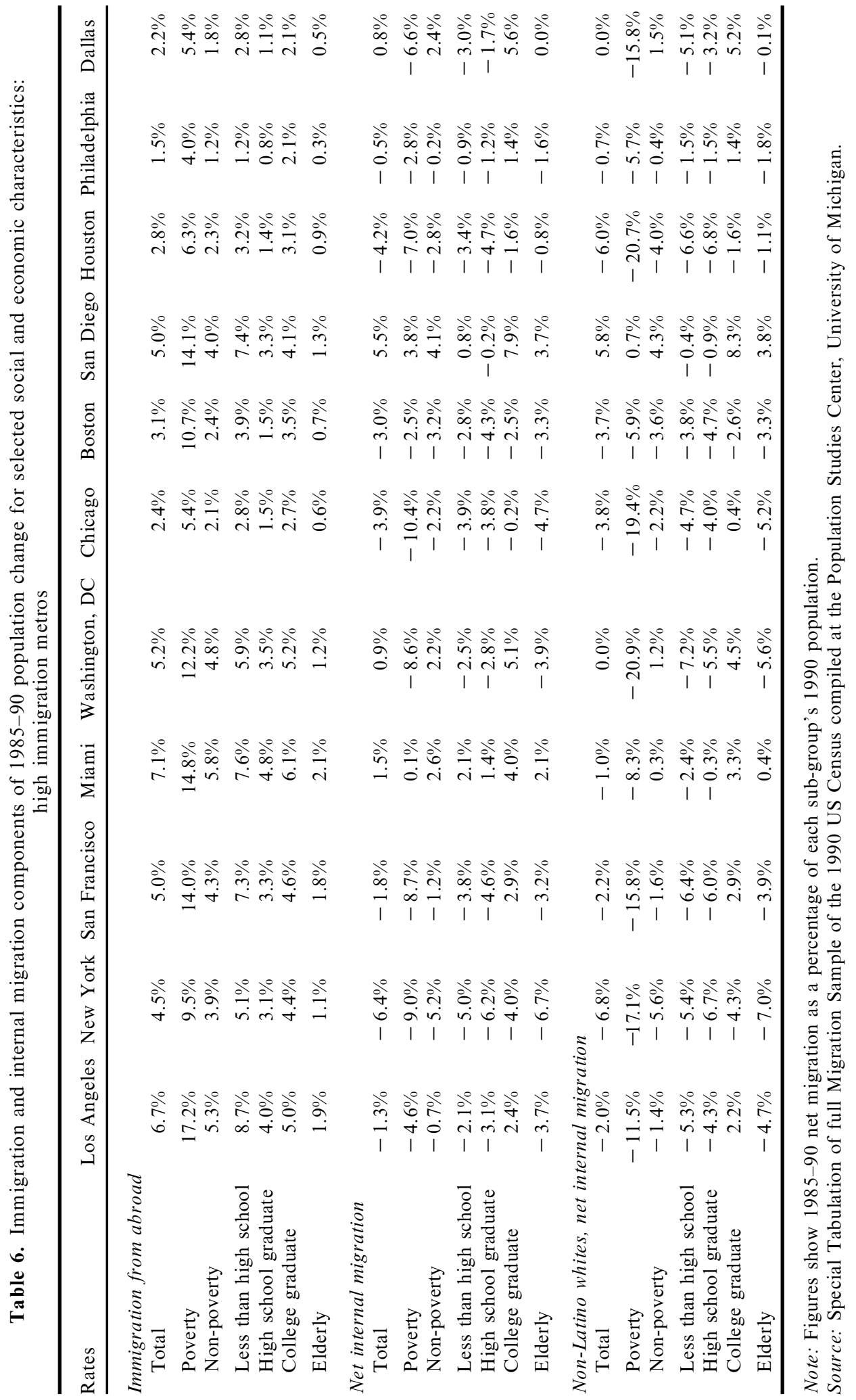




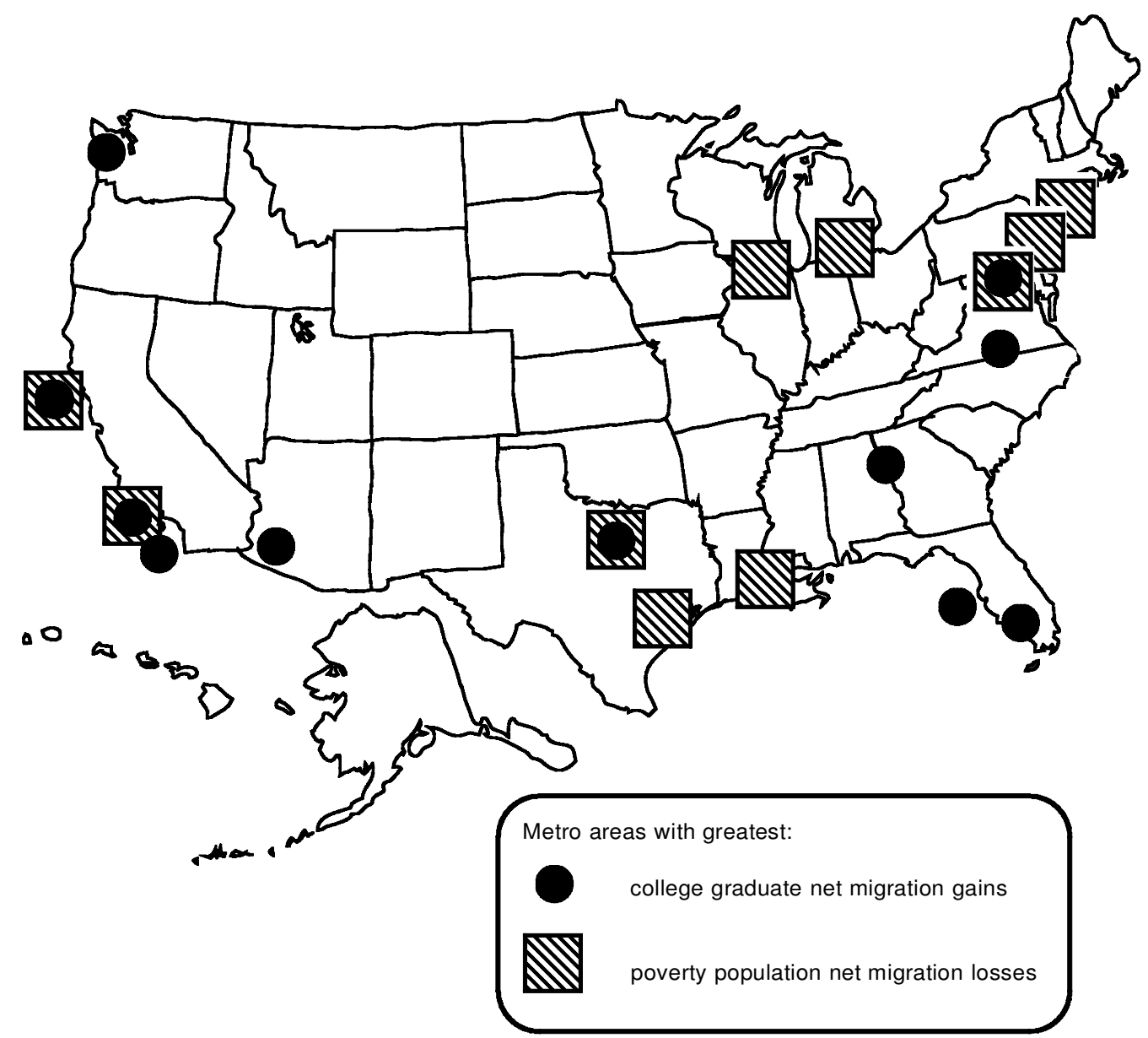

Figure 5. Metro area net internal migration, 1985-90: college graduates and the poverty population.

where (Frey, 1994b) suggests that the college graduate and non-poverty migrants are arriving from other parts of the US, whereas the poverty and less-educated migrants represent the outflow from high immigration metros in California.

Turning now to the other side of the 'circulation of 'elites' equation, it was expected that the selective out-migration from high out-migration metros will come disproportionately from the upper socio-economic strata. This expectation is not fully realised, according to the migration percentages shown in Table 8 that is, in several metropolitan areas (e.g. Detroit, Denver, St Louis), percentages of poverty net out-migration and less than college graduate net out-migration are slightly greater than those for the more well-off and better-educated population segments. How- ever, these disparities are not nearly as sharp as those shown for the out-migration patterns in high immigration metro areas. In addition, areas where the economy is clearly foundering during this period performed much more closely to the 'circulation of 'elites' model. In Pittsburgh, New Orleans and Buffalo, out-migration was much more pronounced among college graduates and the non-poverty population than for the other population groups. Clearly, the impact of immigration does not weigh heavily on the selective out-migration from these metro areas.

\section{Immigration Effects on Internal Mi- gration}

The evidence presented thus far makes the strong suggestion that immigration exerts a 
MIGRATION AND US METROPOLITAN AREAS

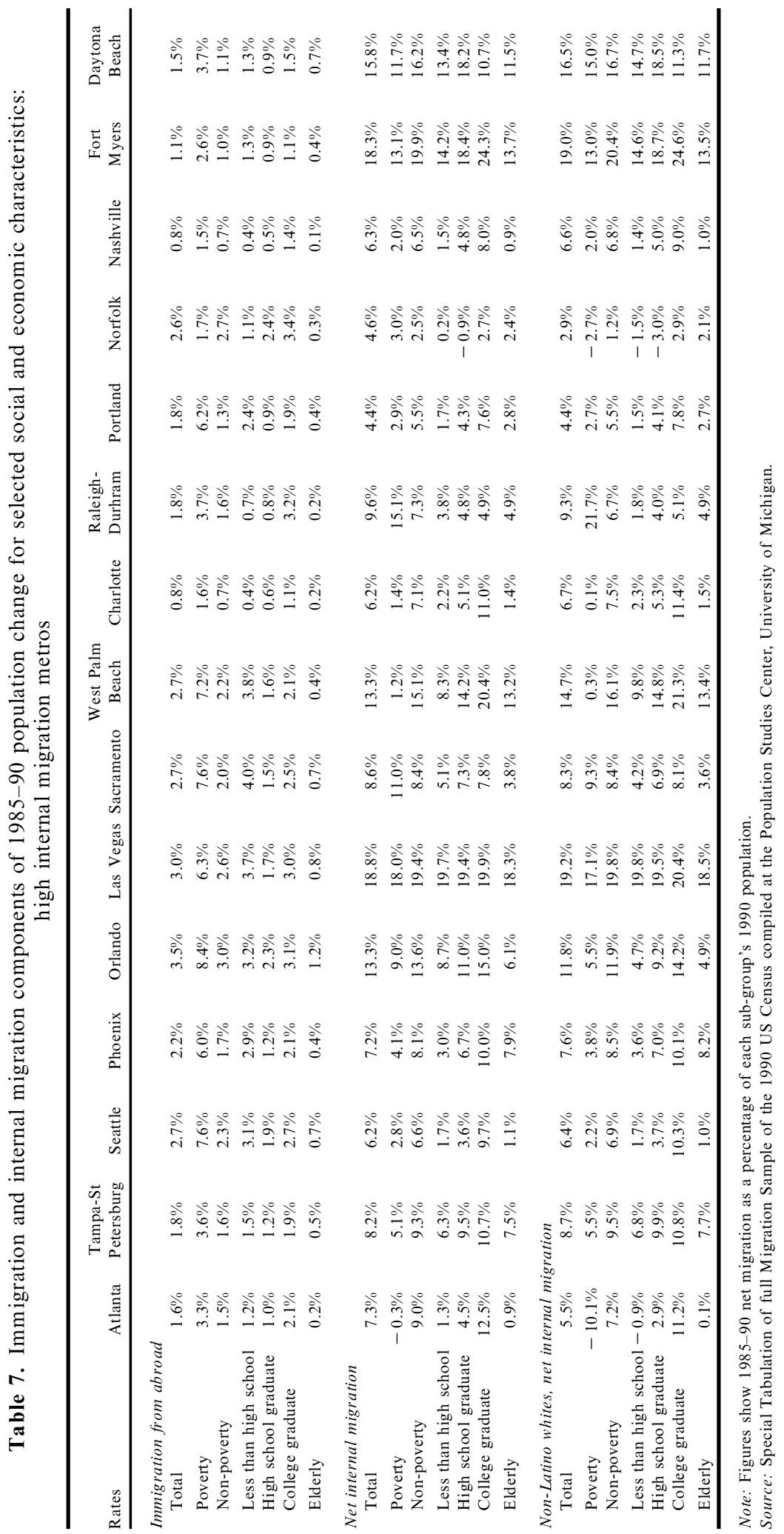




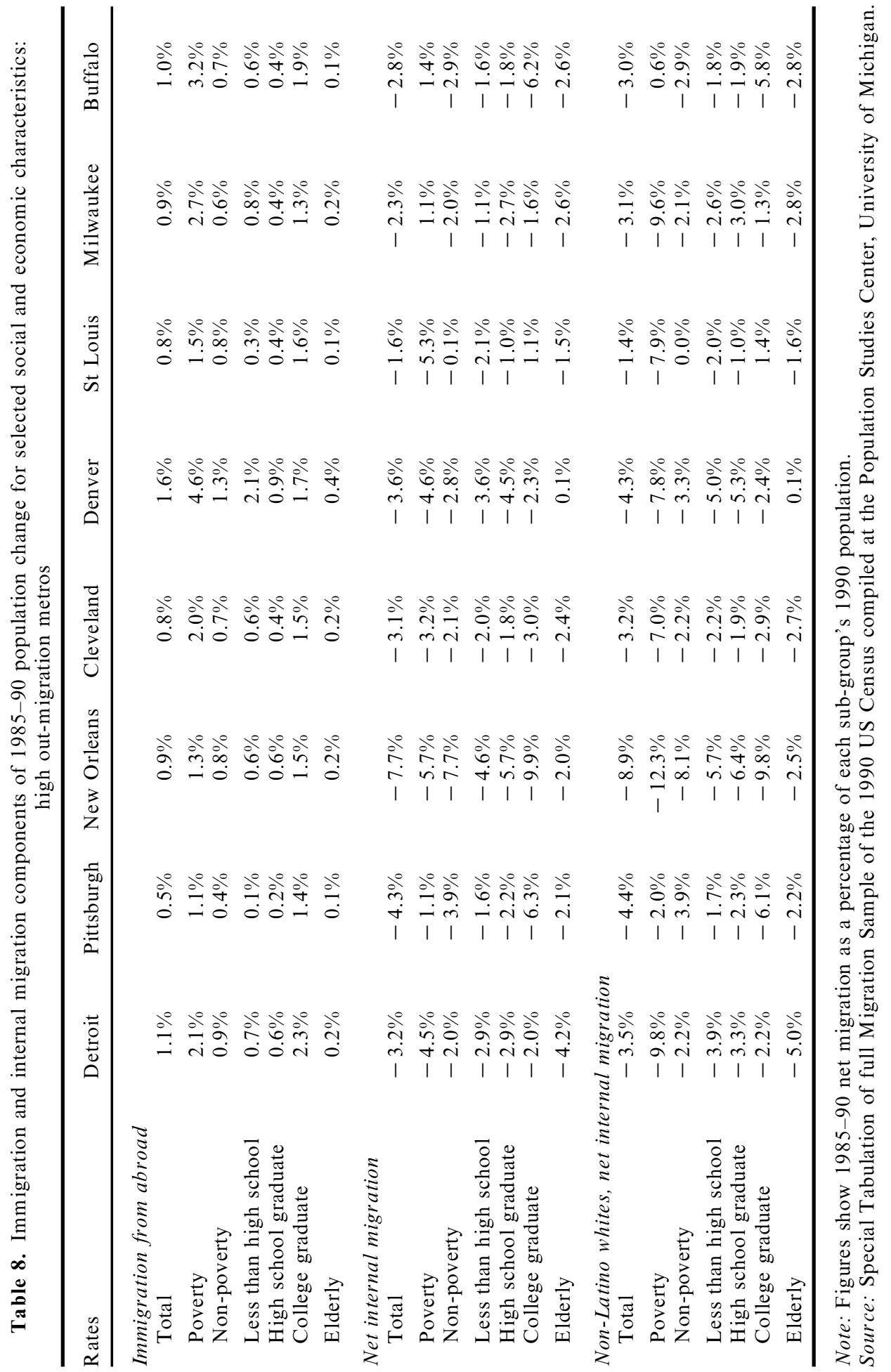


pronounced impact on both the magnitude and the selectivity of out-migration from high immigration metro areas. A more formal statistical test of this assertion is conducted here in a series of multivariate regression equations. In these equations, the dependent variable is the internal migration level for the metropolitan area's population or for a specific demographic sub-group of that metropolitan area's population (e.g. by poverty status, education attainment or the elderly). These regressions are undertaken for the purpose of determining whether immigration over the 1985-90 period exerts an independent negative effect on internal migration when other economic and geographical factors are taken into account.

The other factors included in the analyses are a geographical region classification (dummy variables for the Northeast region, the Midwest region, the South Atlantic division, the Mountain division and the Pacific division, where parts of the South, that are not included in the South Atlantic division, represent the omitted category); four variables reflecting the metropolitan area's economic structure (unemployment rate of 1988, per capita income in 1988, percentage change in manufacturing employment of 1982-87, and the percentage of males engaged in professional and managerial employment based on the 1990 Census); and the log of the metropolitan area's population size in 1985. In addition, for regression equations pertaining to the Non-Latino white population, a measure of the metropolitan area's 1985 minority percentage (percentage of the population other than Non-Latino whites) is included, as well as an adjustment factor to take into account the way Non-Latino whites were estimated from the migration data (a ratio of the metropolitan area's estimated Non-Latino white population to the actual Non-Latino white population). All the migration and population data were drawn from the 1980 and 1990 US Censuses. The economic characteristics are from the State and Metropolitan Area Data Book, 1991, compiled by the US Bureau of the Census.

Consistent with the earlier discussion, it is expected that immigration from abroad will exert an independent effect on net outmigration and that this effect will be most pronounced for the below-poverty population, for individuals with less than college degrees and for the elderly. The first set of equations, shown on Table 9, pertain to the total population (all races and ethnic groups combined). The standardised regression coefficients in the first column show that immigration does indeed exert a significant negative effect on a metropolitan area's net migration. The other significant influences include the positive effect of the area's recent manufacturing growth and the negative effect of its unemployment. On the region variables, there is a general net out-migration from Northeast and Midwest metro areas owing to their economic downturns over the period, as well as the out-migration of the elderly from colder Frost Belt climates. Metro areas in the Mountain region, especially Phoenix and Las Vegas, have attracted in-migrants both from the eastern part of the country as well as from California.

The remaining equations in Table 9 lend further support regarding immigration's impact on internal out-migration. Contrary to expectations, its effect is not selective on socio-economic sub-groups. Only for college graduates does the standardised regression coefficient, associated with immigration, become considerably reduced. Yet its negative effect on the out-migration of college graduates is still significant. Of the other variables in the equation, only manufacturing growth and Mountain region location exert consistent significant impacts among most population groups (the elderly excepted). Among the remaining metropolitan attributes, the unemployment level has its greatest impact on poverty and lesser-educated populations while a high per capita income has its only significant positive influence on the migration of college graduates. (The negative impact of income for below-poverty $\mathrm{mi}$ gration probably reflects the higher cost of living in high-income areas.) Less-educated populations also are more prone to leave metro areas where upper white-collar occu- 


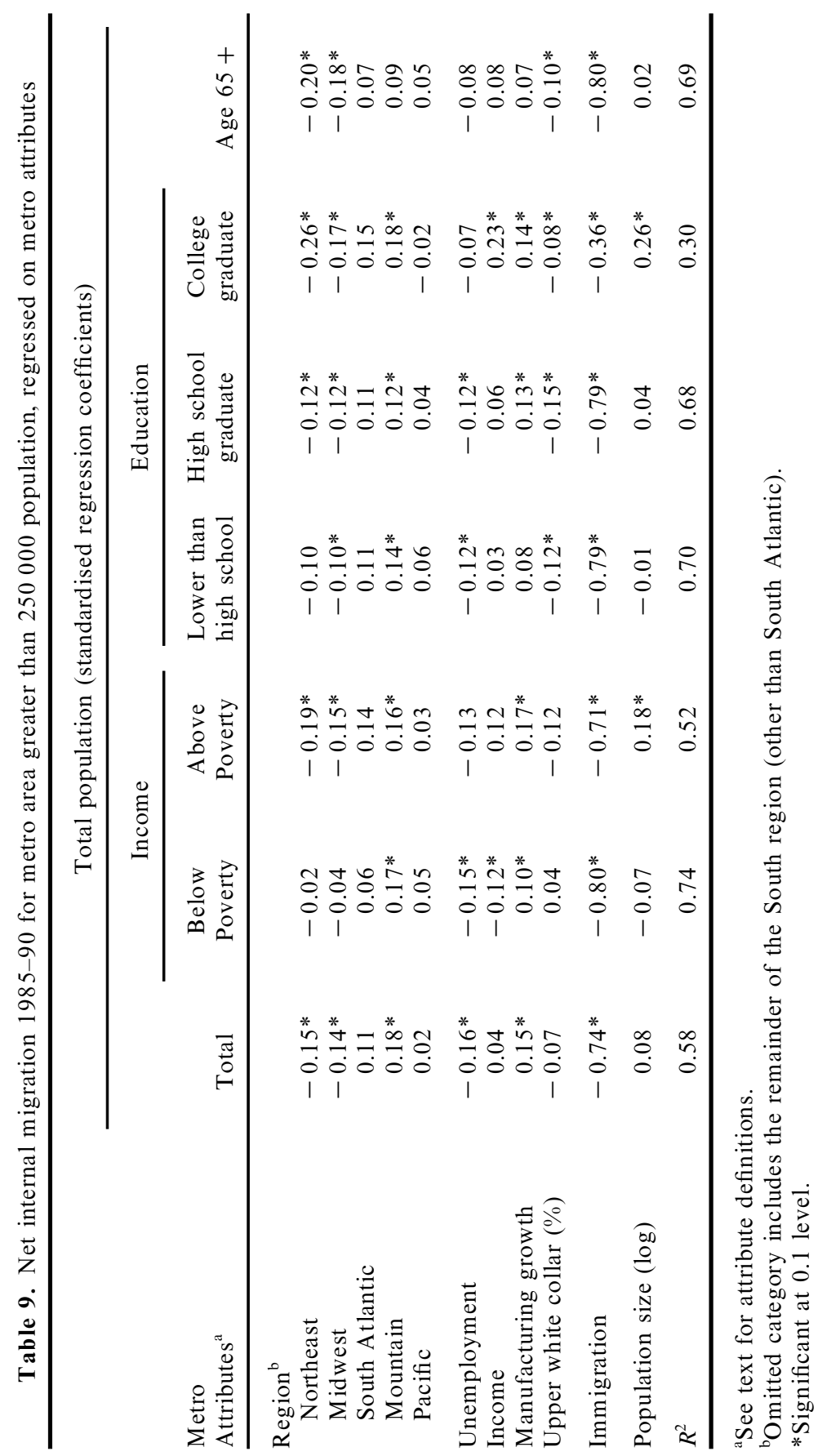




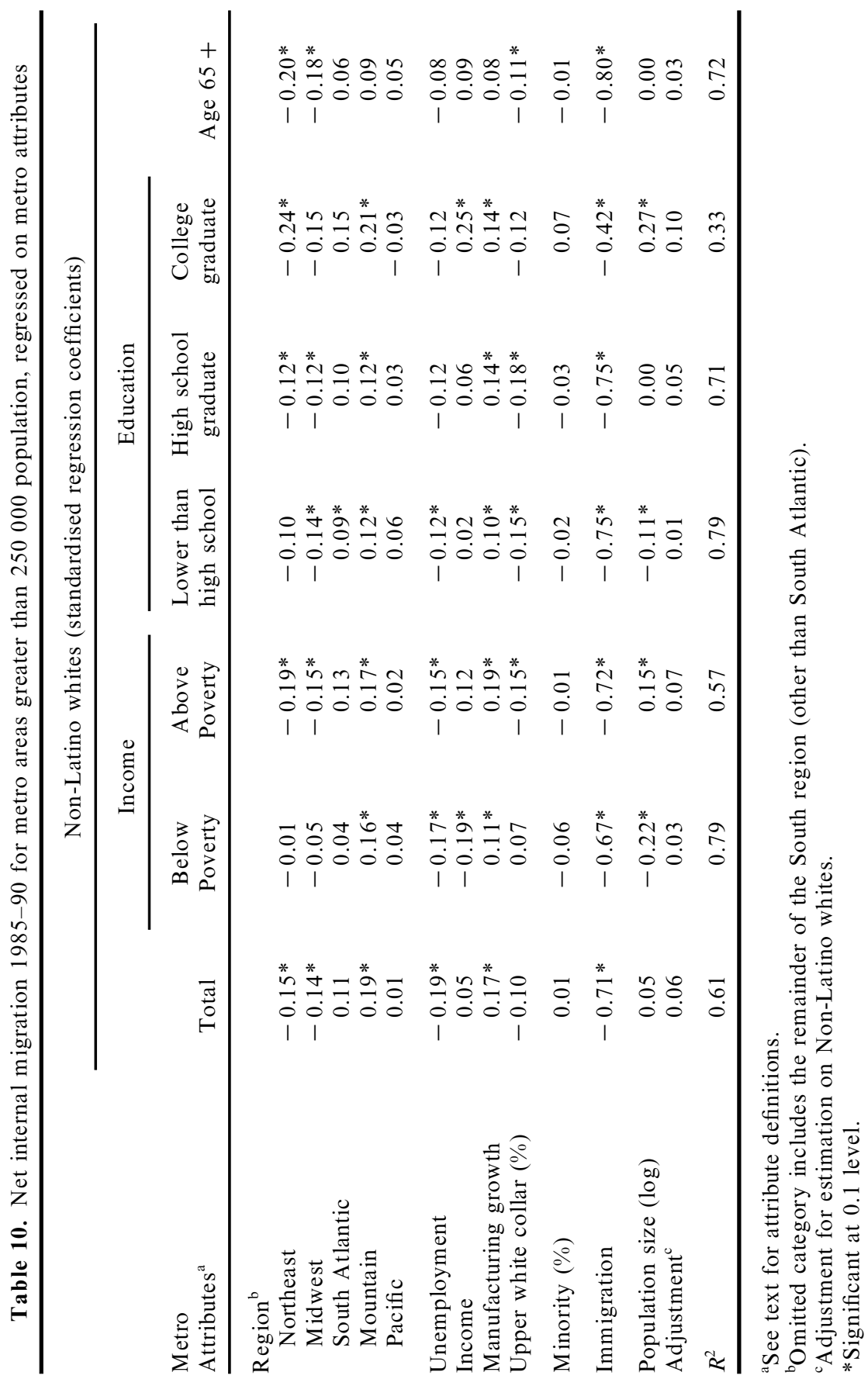


pations are most predominant. Finally, it appears that the negative regional influences associated with the Northeast and Midwest are most important for higher-income, well-educated and elderly segments of the population.

A similar set of regressions were conducted for internal net migration of the Non-Latino white populations in these metropolitan areas (see Table 10). These equations include two additional variables, discussed above. It was anticipated that a metropolitan area's minority percentage might capture the influence that a diverse population might exert on 'white flight' from the area. Yet this variable exerts almost a negligible impact on net internal migration for each of the Non-Latino white sub-groups examined. Moreover, the results for all of the other variables are not appreciably different from those shown in the analysis for the total population. In sum, the consistent negative effect that immigration exerts on the net internal out-migration for the total population also exists for Non-Latino whites.

While these regression equations present supportive evidence that immigration exerts an independent effect on internal out-migration, this analysis does not permit a specification of precisely why this is occurring. It is probably attributable to some combination of economic, housing and social considerations. While the equations have incorporated some of the standard economic factors, as well as a measure of an area's racial and ethnic diversity, they have not captured all of the economic or social nuances that can be brought to bear on the explanation. Nonetheless, the equations do establish the overall importance of immigration in affecting metropolitan area internal migration patterns over the 1985-90 period. Its effect is consistent across all sub-groups with the slight diminution for the college graduate population.

\section{Conclusion}

This article examines the migration dynamics underlying the uneven race and ethnic demographic growth patterns which are character- ising the revival of urban growth in the US (Frey, 1993a). The findings make clear that recent immigration to the US plays a significant role in shaping these patterns. The impacts of the recent, increasing volume of immigration to the US has become the subject of much debate among academics, government officials and policy analysts (Fix and Passel, 1994; Martin and Midgley, 1994; Briggs, 1992; Borjas and Freeman, 1992; Borjas, 1994; US General Accounting Office, 1994; Clark et al., 1994; Brimelow, 1992). Yet most of these debates centre around the effects recent immigration holds for job displacement of specific demographic groups, or the effects that both legal and illegal immigrants impose upon government expenditures. The findings presented here suggest that immigration holds important implications for broad internal redistribution patterns of the US population-both directly, and indirectly by influencing an internal migration which is selective on race and socio-economic status.

This analysis of 1990 census migration data points up the distinction between major metropolitan areas that are impacted most heavily by immigration from abroad; and areas where internal migration represents the greatest component of change. This distinction will be of increasing importance given the focused nature of the larger, more diverse immigrant streams to the US, and the emerging distinction that is being created across broad areas of the country on the basis of their dominant migration dynamics. The metropolitan area typology presented here suggests that there is a clear distinction between metropolitan areas that can be classed as high immigration metros, and other classes of metropolitan areas where population changes are more greatly affected by economic cycles and other forces which determine the ebbs and flows of internal migration streams. To the extent that immigrants continue to flow to traditional 'port-of-entry' areas, these areas will become more demographically distinct as a result of:

(1) the focused arrival of largely minority immigrants; 
(2) the out-movement of largely white internal migrants; and

(3) a 'push-pull' relationship between immigration and a unique selective outmigration of internal migrants.

The internal out-migration directed away from high immigration metropolitan areas is unique in the sense that it is not selecting out the 'best and brightest' of the area's migrants, which is the case with more conventional long-distance migration. Rather, it represents more of a mirror image of the demographic characteristics associated with immigrants to these areas in terms of skills, education and income but is disproportionately selective on whites. At the individual metropolitan area level, this means that immigrant displacement of whites will be most evident among population segments where immigrants and minorities are more greatly represented. Already in 1990, whites constitute a minority of California's population in the following segments: college dropouts, persons living in households with less than twice the nation's poverty income, persons under age 25, and males working in service, farming and manual occupations (Frey, 1993b, 1995b).

On a national scale, it portends a pattern of demographic balkanisation rather than an even increase in racial and ethnic diversity across all regions and metropolitan areas. While the geographical boundaries of what might be considered as 'high immigration areas' may not coincide precisely with either states or even metropolitan areas, they appear to be broader than the local neighbourhood or city-suburb distinctions which framed our earlier thinking about demographic differences across space. These emerging regions will have decidedly younger, more vibrant, ethnically diverse populations than the older, more staid, 'whiter' populations that will characterise other broad geographical areas. They will forge changes in the nation's social and demographic make-up which hold consequences that cannot yet be foreseen. Of course, this scenario assumes that the uneven racial and ethnic growth patterns, observed over the recent period, will continue into the decade ahead. This appears to be driven, in large part, by a focused immigration of new racial and ethnic minorities with bimodal skill distributions which represent the outcomes of current immigration laws and practices in the US. ${ }^{4}$ It also assumes that there will not be a broader geographical dispersion and assimilation of the new immigrant minorities with increasing duration of residence in the country, and that the internal migration response to new immigrants-characterised here as 'flight' - will continue. These are strong assumptions which warrant continued monitoring and research. Nonetheless, the results of the 1990 US census make plain that, as in other developed countries which are absorbing large immigrant flows (Champion, 1994), recent immigration to the US holds important consequences for the nation's social and political geography.

\section{Notes}

1. Migration data utilised here were compiled from special full-sample migration tabulations of the 1990 census based on the "residence 5-years ago" item. Most tables correspond to the population aged 5 and above in 1990, although tabulations for education attainment pertain to the population aged 25 and above, and tabulations for poverty status pertain to persons aged 5 and above for whom poverty status was determined. Net internal migration for a given area (state or metropolitan area) is determined by subtracting 1985-90 out-migrants to other parts of the US, from 1985-90 inmigrants from other parts of the US. Migration from abroad measures persons who resided in the US in 1990 but abroad in 1985. This measure includes some persons who were US citizens working abroad in 1985, although the total flows are predominantly made up of immigrants. The illegal immigrant population to the US is difficult to measure and the census count underestimates this part of the immigrant population. (See Levine et al., 1985, and Woodrow-Lafield, 1994, for a discussion of illegal immigration estimates.)

2. Because race and Latino status (or Hispanic status) are two different concepts in the US census, it is possible to distingu ish between Latino whites and Non-Latino whites. For 
convenience, the term 'whites' will be used to denote Non-Latino whites in this article.

3. These definitions are consistent with CMSA, MSA and, in New England, NECMA counterparts as defined on 30 June 1990 by the US Office of Managem ent and Budget.

4. The race-ethnic and demographic make-up of immigrants to the US has become altered over the years as a result of changing national origins and family or employment preferences among legal immigrants, as well as refugee policies and demographic characteristics of illegal immigrants (see Fix and Passel, 1994; Martin and Midgley, 1994; Borjas, 1994; Kramer and Lowell, 1992; Lowell, 1994). The US Commission on Immigration Reform is currently evaluating US immigration policy for purposes of making recommendations regarding its implementation and effects (Martin, 1993).

\section{References}

Barringer, H.R., Gardner, R.W. and Levin, M.J. (1993) Asians and Pacific Islanders in the United States. New York: Russell Sage.

BARTEl, A.P. (1989) Where do the new immigrants live?, Journal of Labor Economics, 7, pp. 371-391.

BARTEL, A.P. and KoCH, M.J. (1991) Internal migration of U.S. immigrants, in: J.M. A BOWD and R.B. FreEMAN (Eds) Immigration Trade and the Labor Market, pp. 121-134. Chicago: University of Chicago Press.

BEAn, F.D. and TIEndA, M. (1987) The Hispanic Population of the United States Census Monograph. New York: Russell Sage.

BOLtON, N. (1993) Immigration, migration and the labour force of California, UCLA Business Forecast, March.

BorJas, G.J. (1994) The economics of immigration, Journal of Economic Literature, 32, pp. 1667-1717.

Borjas, G.J. and Freeman, R. (1992) Immigration and the Work Force. Chicago: University of Chicago Press.

BRIGGS, V., JR (1992) Mass Immigration and the National Labor Market Armonk, New York: M. E. Sharpe, Inc.

Brimelow, P. (1992) Time to rethink immigration?, National Review, 22 June, pp. 30-46.

Center for ImMigration Studies (1994) Backgrounder.

Champion, A.G. (1994) International migration and demographic change in the developed world, Urban Studies, 31, pp. 653-678.

Chiswick, B.R. and Sullivan, T.A. (1995) The new immigrants, in: R. FARLEY (Ed.) The State of the Union: Social Trends, ch. 5. New York: Russell Sage.
Clark, R.L., Passel, J.S., Zimmerman, W.N. and FIX, M. (1994) Fiscal Impacts of Undocumented Aliens: Selected Estimates for Seven States. Washington, DC: The Urban Institute.

FILER, R.K. (1992) The effect of immigrant arrivals on migratory patterns of native workers, in: G.J. BORJAS and R.B. FreEMAN (Eds) Immigration and the Work Force, pp. 245-270. Chicago: University of Chicago Press.

FIX, M. and PAssel, J. (1991) The Door Remains Open: Recent Immigration to the United States and a Preliminary Analysis of the Immigration Act of 1990. Washington, DC: The Urban Institute.

FIX, M. and PAssel, J. (1994) Immigration and Immigrants' Setting the Record Straight. Washington, DC: The Urban Institute.

FrEY, W.H. (1979) The changing impact of white migration on the population compositions of origin and destination metropolitan areas, Demography, 16, pp. 219-238.

FreY, W.H. (1993a) The new urban revival in the United States, Urban Studies, 30, pp. 741-774.

FREY, W.H. (1993b) Inter-state migration and immigration for whites and minorities, 198590: the emergence of multi-ethnic states. Research Report No. 93-297, Population Studies Center, University of Michigan, Ann Arbor.

FrEy, W.H. (1994a) The new white flight, American Demographics, April, pp. 40-48.

FREY, W.H. (1994b) College grad, poverty blacks take different migration paths. Research Report No. 94-303, Population Studies Center, University of Michigan, Ann Arbor.

FREY, W.H. (1994c) Immigration and internal migration 'flight' from U.S. metro areas: 1990 Census findings by race, poverty, and education. Research Report No. 94-304, Population Studies Center, University of Michigan, Ann Arbor.

FREY, W.H. (1994d) Immigration and internal migration for US states: 1990 Census findings by poverty status and race. Research Report No. 94-320, Population Studies Center, University of Michigan, Ann Arbor.

FREY, W.H. (1995a) The new geography of US population shifts: trends toward balkanization, in: R. FARLEY (Ed.) The State of the Union: Social Trends, pp. 271-336. New York: Russell Sage.

FrEY, W.H. (1995b) Immigration and internal migration 'flight': a California case study, Population and Environment, 16, pp. 353-375.

FREY, W.H. (1995c) Elderly demographic profiles of US states: aging-in-place, migration and immigration impacts. Research Report, No. 95325, Population Studies Center, University of Michigan, Ann Arbor.

Frey, W.H. and Speare, A., JR. (1988) Regional 
and Metropolitan Growth and Decline in the United States. New York: Russell Sage.

Johnson, J.H., JR and Roseman, C.C. (1990) Increasing black out-migration from Los Angeles: the role of household dynamics and kinship systems, Annals of the Association of American Geographers, 80, pp. 205-222.

Kramer, R.G. and Lowell, B.L. (1992) Employment-based immigration: the rationale and politics behind the Immigration Act of 1990. Paper presented at The Population Association of America Annual Meeting, Denver.

Lansing, J.B. and Mueller, E. (1967) The geographic mobility of labor. Survey Research Center, Institute for Social Research, Ann Arbor.

Levine, D.B., Hill, K. and Warren, R. (Ed.) (1985) Immigration Statistics: A Story of $\mathrm{Ne}$ glect. Washington, DC: National Academy Press.

Long, L. (1988) Migration and Residential Mobility in the United States. New York: Russell Sage.

Longino, C.F., JR (1984) Migration winners and losers, American Demographics, 6, pp. 27-29, 45.

Longino, C.F., JR (1990) Geograph ic distribution and migration, in: R.H. BINSTOCK and L.K. George (Eds) Handbook of Aging and the Social Sciences, 3rd ed, pp. 45-63. San Diego: Academ ic Press.

LowElL, B.L. (1994) Skilled and family-based immigration: principles and labor markets, in: Proceedings of the 15th Annual Middlebury College Conference on Economic Issues.

Manson, D.M., Espenshade, T.J. and Muller, T. (1985) Mexican immigration to southern California: issues of job competition and worker mobility, The Review of Regional Studies, 15, Spring, pp. 21-33.

Martin, P. and Midgley, E. (1994) Immigration to the United States: journey to an uncertain destination, Population Bulletin, 49(2), Washington, DC: Population Reference Bureau.

Martin, S.F. (1993) The Commission on Immigration Reform, Migration World, 21(2), pp. 43-44.

Massey, D., Alarcon, R., Durand, J. and GonZAles, H. (1987) Return to Aztlan: The Social Process of International Migration from Western Mexico. Berkeley, CA: University of California Press.

MCHugh, K.E. (1987) B lack migration reversal in the United States, Geographical Review, 77, pp. 171-187.
McHugh, K.E. (1988) Determinants of black interstate migration, $1965-70$ and 1975-80, Annals of Regional Science, 22, March, pp. 36-48.

McHugh, K.E. (1989) Hispanic migration and population redistribution in the United States, Professional Geographer, 41(4), pp. 429-439.

Mollenkopf, J.H. and CAstells, M. (Eds) (1991) Dual City: Restructuring New York. New York: Russell Sage.

Roberts, S. (1993) Who We Are: A Portrait of America based on the Latest US Census. New York: Times Books.

Rogers, A. (1992) Elderly migration and population redistribution in the United States, in: A. ROGERS (Ed.) Elderly Migration and Population Redistribution: A Comparative Perspective, pp. 26-248. London: Belhaven Press.

Rogers, A. and Watkins, J.F. (1987) General versus elderly interstate migration and population redistribution in the United States, Research on Aging, 9(4), pp. 483-529.

Speare, A. JR, Goldstein, S. and Frey, W.H. (1975) Residential Mobility, Migration and Metropolitan Change. Cambridge, MA: Ballinger Publishing Co.

Tilove, J. and Hallinan, J. (1993) Whites flee immigrants: flee white states, Newark Star Ledger, 8 August, p. 1.

US General ACCOUnTING Office (1994) Illegal Aliens: Assessing Estimates of Financial Burden on California, GAO/HEHS-95-22.

WALDINGER, R. (1989) Immigration and urban change, Annual Review of Sociology, 15, pp. 211-232.

W AlKer, R., Ellis, M. and BARFF, R. (1992) Linked migration systems: immigration and internal labor flows in the United States, Economic Geography, 68, pp. 234-248.

White, M.J. and Hunter, L. (1993) The migratory response of native-born workers to the presence of immigrants in the labor market. Paper presented at the 1993 meetings of the Population Association of America, Cincinnati, April.

White, M.J. and ImAI, Y. (1994) The impact of immigration upon internal migration, Population and Environment, 15(3), pp. 189-209.

Woodrow-LAFIELD, K.A. (1994) Finding an upper limit on recent net undocumented migration to the United States. Center for Social and Demographic Studies, State University of New York, Albany. 